\title{
PENAMPILAN PRODUKSI AYAM KAMPUNG SUPER MELALUI PENAMBAHAN JUICE DAUN GEDI (Abelmochus Manihot L. Medik) DALAM AIR MINUM
}

\author{
Cindy C Jacob, Jein R. Leke*, Cherlie L.K. Sarajar, Linda M.S. Tangkau \\ Fakultas Peternakan, Universitas Sam Ratulangi Manado
}

\begin{abstract}
ABSTRAK
Penelitian ini dilakukan dengan tujuan mengetahui penampilan produksi ayam kampung super melalui penambahan Juice Daun Gedi (Abelmochus Manihot L. Medik) dalam air minum. Penelitian selama 7 minggu menggunakan 100 ekor ayam kampung super. Perlakuan terdiri dari : $\mathrm{PO}=$ air minum tanpa jus daun gedi(JDG), $\mathrm{P} 1=10$ $\mathrm{mL}$ (JDG), P2 = $20 \mathrm{~mL}$ (JDG), P3 = $30 \mathrm{~mL}$ (JDG). Pakan yang diberikan adalah pakan komersial $73 \%$, jagung $10 \%$, dedak halus 17\%. Penelitian ini menggunakan metode Rancangan Acak Lengkap (RAL) terdiri dari 4 perlakuan dan 5 ulangan. Jika terdapat perbedaan rataan perlakuan dilanjutkan dengan uji Duncan. .Variabel yang diukur adalah berat akhir, berat potong, berat karkas dan persentase karkas.Hasil analisis data menunj ukan bahwa penambahan juice daun gedi Gedi (Abelmochus Manihot L. Medik) dalam air minum ayam kampong super memberikan pengaruh berbeda tidak nyata $(\mathrm{P}$ $>0.05)$ terhadap berat akhir, berat potong, berat karkas dan persentase karkas. Berdasarkan hasil penelitian dapat disimpulkan bahwa penambahan juice daun gedi (Abelmochus Manihot L. Medik) pada $10 \mathrm{~mL}-30 \mathrm{~mL}$ memberikan respon yang baik terhadap berat akhir, berat potong, berat karkas dan persentase karkas ayam kampung super.
\end{abstract}

Kata kunci : Ayam Kampung Super, Juice Daud Gedi, Penampilan Produksi

*Kosepondensi (corresponding author)

Email : rinileke@unsrat.ac.id
ABSTRACT

APPEARANCE OF SUPER
NATIVE CHICKEN PRODUCTION
TROUGH ADDITION OF GEDI LEAF
JUICE (ABELMOCHUS MANIHOT L.
MEDIK) IN DRINKING WATER. This
research was conducted with the aim to
determine the appearance of super native
chicken production trough the addition of
gedi leaf juice (Abelmochus Manihot L. Medik) in drinking water. 7 week of research using 100 super native chicken. Treatmen consists of $\mathrm{PO}=$ drinking water without (JDG), P1= $10 \mathrm{~mL}$ (JDG), P2 = $20 \mathrm{~mL}$ (JDG), $\mathrm{P} 3=30 \mathrm{~mL}$ (JDG). Feed were using $73 \%$ of commercial feed, $10 \%$ of corn , $17 \%$ of rice bran. This research uses a completely randomized design method consisting of 4 treatments and 5 replication. The variabels measured were final weight, cut weight, carcass weight and carcass percentage. The result of data analysis showed that the addition of gedi leaf juice (Abelmochus Manihot L. Medik) in drinking water of super native chicken had a significantly different effect $(\mathrm{P}>0.05)$ on the final weight, cutting weight, carcass weight and percentage of carcass. The result of the research on the addition of gedi leaf (Abelmochus Manihot L. Medik) juice in drinking water to $30 \mathrm{ml} /$ liter of drinking water give a good response to final weight, cut weight, carcass weight and carcass percentage of super native chicken.

Keyword : Appearance Production, Gedi Leaf Juice, Super Native Chicken 


\section{PENDAHULUAN}

Ayam kampung super sudah dikenal masyarakat Indonesia, di pedesaan maupun di perkotaan sebagai penghasil daging dan telur. Ayam kampung super merupakan ayam persilangan antara ayam kampung jantan dan ayam petelur (ras). Ayam persilangan bertujuan untuk perbaikan genetik sehingga dihasilkan ayam dengan produktivitas yang lebih baik. Dewasa ini permintaan akan produk ayam kampung super meningkat secara tajam, baik di pasar tradisional dan swalayan. Dengan adanya kemajuan era digital sehingga permintaan ayam kampung super yang terjual di pasaran sudah dalam keadaan "Ready To Cook" siap untuk dimasak. Permintaan pasar akan ayam kampung super tidak diimbangi dengan ketersediaanya di pasaran karena peternak ayam kampung super yang juga masih sedikit. Hal ini dapat terlihat pada penjualan produk ayam di pasar swalayan.

Penggunaan pakan dari bahan alami tanaman herbal merupakan cara alternatif untuk meningkatkan penampilan produksi ternak, dan dapat mencegah penyakit. Pemanfaatan tanaman obat sebagai zat aditif telah dibuktikan dengan teknik modern sebagai bahan yang alami, bebas residu dan tidak beracun. Daun gedi (Abelmochus
Manihot L. Medik) adalah salah satu jenis tanaman yang dikategorikan dalam kelompok tanaman obat/herbal. Tanaman gedi memiliki potensi anti-flamatori, antibakteri, antiviral, antioksidan, serta dapat mengeliminasi radikal bebas. Potensi tanaman gedi sebagai obat karena tanaman ini mengandung zat-zat yang mampu mengefisienkan makanan didalam saluran pencernaan ternak dan untuk mencapai bobot ayam pedaging yang maksimal, juga untuk memenuhi kebutuhan konsumen akan produk peternakan yang aman dan sehat.

Penggunaan juice daun gedi dalam pakan ayam pedaging ternyata menurunkan konsumsi pakan dan pertambahan berat badan. Tetapi konversi pakan dan persentase karkas ada dalam kategori baik serta persentase lemak abdominal sangat nyata menurun. Hasil penelitian terhad ap daun gedi dalam bentuk juice daun gedi yang diberikan melalui air minum pada ayam pedaging mendapatkan hasil berat badan yang lebih tinggi dibanding ketika diberikan melalui ransum (Mandey dan Pontoh, 2016). Namun dari segi komersial belum optimal menghasilkan daging ayam dengan berat pasar. Hal ini terjadi karena daun gedi mengandung musilase yang tinggi.

Penelitian pemanfaatan juice daun gedi pada ayam kampung super belum 
pernah dilakukan, karen itu penelitian ini bertujuan untuk mengetahui penampilan produksi ayam kampung super yang diberi juice daun gedi (Abelmochus Manihot L. Medik) dalam air minum.

\section{MATERI DAN METODE PENELITIAN}

Penelitian ini telah dilakukan melalui percobaan selama 7 minggu, yang terdiri dari 6 hari masa pendahuluan dan 36 hari masa pengambilan data. Ternak yang digunakan ayam kampung super umur 7 minggu sebanyak 100 ekor dengan rata-rata berat badan awal 456 gram/ekor, menggunakan 20 unit kandang dan masing-masing kandang ditempati 5 ekor ayam kampung super. Peralatan yang digunakan yaitu thermometer, gunting, pisau, kantong plastik, ember, koran bekas, kandang battery dan timbangan digital. Pakan disusun sesuai kebutuhan ayam kampung super, Pakan yang diberikan adalah pakan komersial $73 \%$, jagung 10\%, dedak halus $17 \%$.

Pembuatan juice daun gedi: Daun gedi segar dicuci dengan air bersih, dipotong lalu diblender, dengan perbandingan $100 \mathrm{~g}$ daun gedi ditambah 1 liter air kemudian dimasukan dalam wadah dan disimpan dalam kulkas. Juice daun gedi yang diberikan terd iri dari perlakuan:

$\mathrm{P} 0=1 \mathrm{~L}$ air minum tanpa $(\mathrm{JDG})$

$\mathrm{P} 1=1 \mathrm{~L}$ air minum $+10 \mathrm{~mL}(\mathrm{JDG})$

$\mathrm{P} 2=1 \mathrm{~L}$ air minum $+20 \mathrm{~mL}(\mathrm{JDG})$

$\mathrm{P} 3=1 \mathrm{~L}$ air minum $+30 \mathrm{~mL}(\mathrm{JDG})$

Penelitian ini menggunakan metode Rancangan Acak Lengkap (RAL) menurut (Steel dan Torrie, 1995) terdiri dari 4 perlakuan dan 5 ulangan menggunakan 5 ekor ayam kampung super. Jika terdapat pengaruh yang sangat nyata diikuti uji Duncans.

Variabel yang diukur adalah:

1. Berat Akhir : Untuk mengukur berat akhir dilakukan penimbangan berat akhir per ekor ayam pada akhir periode pemeliharaan (36 hari).

2. Berat Potong : Berat akhir ayam yang telah dipuasakan selama 8 jam sebelum dipotong.

3. Berat Karkas : Berat ayam setelah dipotong dikurangi dengan darah, bulu, kepala, kaki, dan alat pencernaan.

4. Persentase Karkas : Nilai persentase karkas diperoleh dengan membandingkan bobot karkas (gram) dengan berat hidup dikali $100 \%$. 
Tabel 1. Komposisi dan Kandungan Zat-zat Makanan Bahan Pakan

\begin{tabular}{lcccc}
\hline Zat-Zat Makanan & $\begin{array}{c}\text { Pakan } \\
\text { Komersial* }\end{array}$ & Daun Gedi* & Jagung ** & Dedak Halus** \\
\hline Bahan Kering & 93,38 & 81,72 & - & - \\
Protein Kasar (\%) & 22,34 & 20,18 & 9,42 & 13,44 \\
Serat Kasar (\%) & 4,66 & 17,53 & 2,15 & 6,35 \\
Lemak (\%) & 3,15 & 1,06 & 5,17 & 6,07 \\
Beta-N (\%) & 57,26 & 31,17 & - & - \\
Ca (\%) & 1,28 & 3,29 & 0,22 & 0,19 \\
P (\%) & 0,71 & 0,39 & 0,6 & - \\
Metionin (mg/g) & 17 & 16 & - & - \\
LISIN (mg/g) & 47 & 425 & - & - \\
GE (Kkal/kg) & 3685 & 3419 & - & - \\
Me (Kkal/kg) & 2900 & - & 3182 & 2695 \\
\hline
\end{tabular}

Sumber : * Mandey (2013); ** Dengah (2016)

Tabel 2. Komposisi Pakan Percobaan

\begin{tabular}{lc}
\hline Komposisi Pakan Percobaan & Jumlah \\
\hline Pakan Komersial (\%) & 73 \\
Jagung (\%) & 10 \\
Dedak Halus (\%) & 17 \\
\hline Total & 100 \\
\hline
\end{tabular}

Tabel 3. Komposisi Nutrien Pakan Percobaan

\begin{tabular}{lc}
\hline Nutrien & Komposisi \\
\hline Protein Kasar (\%) & 19,49 \\
Lemak (\%) & 3,63 \\
Serat Kasar (\%) & 4,66 \\
$\mathrm{Ca}(\%)$ & 1,02 \\
P (\%) & 0,66 \\
ME (kkal/kg) & 2920 \\
\hline
\end{tabular}




\section{HASIL DAN PEMBAHASAN}

Hasil Penelitian Penambahan Juice Daun Gedi Pada Air Minum Terhadap Penampilan Produksi Ayam Kampung Super dapat dilihat Pada Tabel 4.

\section{Pengaruh Penambahan Juice Daun Gedi Pada Air Minum Terhadap Berat Akhir Ayam Kampung Super}

Berat akhir ayam kampung super umur 12 minggu berkisar antara 1226,6 g/ekor 1287,8 g/ekor tertinggi diperoleh pada perlakuan P1 (penambahan $10 \mathrm{~mL}$ juice daun gedi) dan terendah pada perlakuan P2 (penambahan $20 \mathrm{~mL}$ juice daun gedi).

Hasil analisis ragam menunjukkan bahwa penambahan juice daun gedi dengan level $10 \mathrm{~mL}-30 \mathrm{~mL}$ memberikan pengaruh berbeda tidak nyata $(\mathrm{P}>0,05)$ terhad ap berat akhir ayam kampung super. Hal ini menunjukkan bahwa perlakuan memberikan hasil yang sama terhadap berat akhir. Berat akhir ayam kampung umur 12 minggu adalah 900 g/ekor (Iskandar, 2005). Hasil penelitian ini masih lebih tinggi dibanding dengan penelitian Sukmawati et al. (2015) dengan berat akhir ayam kampung sekitar 771,0 891,54 g/ekor.

Konsumsi pakan dan konsumsi air minum mempengaruhi berat akhir ayam kampung super. Konsumsi pakan yang tidak bebeda nyata menghasilkan berat akhir ayam kampung super yang tidak berbeda. Penelitian Kogoya (2019) menunjukkan konsumsi ransum dengan perlakuan juice daun gedi $10 \mathrm{~mL}-30 \mathrm{~mL}$ tidak memberikan

Tabel 4. Pengaruh Penambahan Juice Daun Gedi Pada Air Minum Terhadap Penampilan Produksi Ayam Kampung Sup

\begin{tabular}{ccccc}
\hline \multirow{2}{*}{ Variabel } & \multicolumn{3}{c}{ Perlakuan } \\
\cline { 2 - 5 } & $\mathrm{P} 0$ & $\mathrm{P}_{1(10 \mathrm{~mL})}$ & $\mathrm{P}_{2(20 \mathrm{~mL})}$ & $\mathrm{P}_{3(30 \mathrm{~mL})}$ \\
\hline Berat Potong (g/ekor) & 1242,2 & 1287,8 & 1226,6 & 1242,6 \\
Berat Potong (g/ekor) & 1104,8 & 1108,8 & 1063,2 & 1085,6 \\
Berat Karkas (g/ekor) & 824,2 & 828,0 & 787,8 & 809,8 \\
Persentase Karkas (\%) & 67,74 & 66,21 & 65,96 & 66,62 \\
\hline
\end{tabular}

Keterangan : tidak bebeda nyata $(\mathrm{P}>0,05)$ 
pengaruh terhadap konsumsi ransum dan konsumsi air minum. Rataan konsumsi pakan yaitu P0 = 2252,04 g/ekor, P1= 2237,52 g/ekor, $\mathrm{P} 2=2254,24$ g/ekor, $\mathrm{P} 3=2248,48$ g/ekor dan konsumsi air minum yaitu P0 = 4918,80 ml/ekor, $\mathrm{P} 1=4892,80 \mathrm{ml} /$ ekor, $\mathrm{P} 2=$ 4937,20 ml/ekor, $\mathrm{P} 3=4856,80$ g/ekor (Kogoya, 2019). Setiadi et al. (2013) mengatakan konsumsi pakan sangat berpengaruh terhadap berat akhir yang dihasilkan. Konsumsi air minum dipengaruhi oleh suhu lingkungan, jumlah pakan dan kualitas pakan yang diberikan (Arifien, 2002).

\section{Pengaruh Penambahan Juice Daun Gedi Pada Air Minum Terhadap Berat Potong Ayam Kampung Super}

Berat potong ayam kampung super umur 12 minggu berkisar antara 1063,2 g/ ekor - 1108,8 g/ekor dengan rataan berat potong tertinggi sampai terendah pada perlakuan P1, P0, P3, P2 yaitu 1108,8 g/ekor, 1104,8 g/ekor, 1085,6 g ekor, 1063,2 g/ekor.

Hasil analisis ragam menunjukkan bahwa perlakuan penambahan $10 \mathrm{~mL}-30 \mathrm{~mL}$ juice daun gedi memberikan pengaruh yang berbeda tidak nyata $(\mathrm{P}>0.05)$ terhadap berat potong ayam kampung super. Hal ini menunjukkan perlakuan memberikan hasil yang sama. Berat potong dalam penelitian ini lebih tinggi di banding dengan penelitian Tasse (2016) berat potong ayam kampung super umur 10 minggu berkisar antara 837,5 g- 903,8 g. Husna et al. (2016) berat potong ayam kampung umur 12 minggu sebesar 713,8 g/ekor. Tidak adanya perbedaan yang nyata ini dikarenakan berat akhir ayam kampung super dalam penelitian ini yang juga memberikan hasil yang sama berkisar antara 1226,6-1287,8 g/ekor. Haryadi (2007) mengatakan bahwa berat potong yang dihasilkan sama karena konsumsi pakan yang juga dihasilkan sama.

\section{Pengaruh Penambahan Juice Daun Gedi Pada Air Minum Terhadap Berat Karkas Ayam Kampung Super}

Rataan berat karkas berkisar antara 787,8 - 828,0 . Berat karkas ayam kampung super tertinggi diperoleh pada perlakuan P1 yaitu 828,0 g/ekor dan terendah pada perlakuan P2 yaitu 787,8 g/ekor.

Hasil analisis ragam menunjukkan bahwa penambahan juice daun gedi $10 \mathrm{~mL}$ $30 \mathrm{~mL}$ memberikan pengaruh yang berbeda tidak nyata $(\mathrm{P}>0.05)$ terhadap berat karkas ayam kampung super. Hal ini menunjukkan perlakuan memberikan hasil yang sama. Rataan berat karkas dalam penelitian ini masih lebih tinggi dari penelitian Tasse (2016) dengan berat karkas yaitu 460 g/ekor - 509,3 g/ekor. Iskandar et al. (2000) bahwa 
berat karkas ayam kampung umur 12 minggu yaitu 659 g/ekor.

Berat karkas yang dihasilkan sama karena berat akhir, dan berat potong dalam penelitian ini juga memberikan hasil yang sama antar perlakuan. Nahashon et al. (2005) mengatakan bahwa berat karkas dipengaruhi oleh berat akhir yang dihasilkan.

\section{Pengaruh penambahan juice daun gedi pada air minum terhadap persentase karkas ayam kampong super}

Rataan persentase karkas ayam kampung super umur 12 minggu berkisar antara $65,96 \%-67,74 \%$,

Hasil analisis ragam menunjukkan bahwa perlakuan dengan penambahan $10 \mathrm{~mL}$ - $30 \mathrm{~mL}$ juice daun gedi memberikan pengaruh yang berbeda tidak nyata $(\mathrm{P}>0.05)$ terhadap persentase karkas ayam kampung super. Hal ini menunjukkan perlakuan memerikan hasil yang sama terhadap persentase karkas ayam kampung super. Persentase karkas dalam penelitian ini masih lebih baik dari hasil penelitian Darmawan et al. (2017) persentase karkas ayam buras super umur 12 minggu yaitu 59,56\% 64,15\%. Penelitian ini sejalan dengan penelitian Mandey (2013) bahwa penggunaan tepung daun gedi $5-15 \%$ memberikan pengaruh yang sama terhadap persentase karkas ayam pedaging. Persentase karkas meningkat seiring dengan meningkatnya berat potong (Soeparno., 1994). Persentase karkas juga dipengaruhi oleh umur potong. Abdullahet et al. (2010) mengatakan persentase karkas akan bertambah seiring bertambahnya umur ayam.

\section{KESIMPULAN}

Berdasarkan hasil penelitian ini dapat disimpulkan bahwa penambahan juice daun gedi (Abelmochus Manihot L. Medik) pada $10 \mathrm{~mL}-30 \mathrm{~mL}$ memberikan pengaruh yang berbeda tidak nyata atau menunjukan hasil yang sama terhadap berat akhir, berat potong, berat karkas dan persentase karkas ayam kampung super.

\section{DAFTAR PUSTAKA}

Abdullah, A. Y., N.A. Al-Beitawi, M.M. Rjoup, R.I. Qudsieh, and M.A.A. Ishmais. 2009. Growth performance, carcass and meat quality characteristics of different commercial crosses of broiler strains of chicken. The journal of poultry science $18(4): 174-180$.

Arifien, M. 2002. Rahasia Sukses Memelihara Ayam Broiler di Daerah Tropis. Penebar Swadaya, Jakarta. 
Darmawan, I., E. Suprijatna, dan U. Atmomarsono, 2017. Pengaruh frekuensi dan periode pemberian pakan terhadap produksi karkas ayam buras super. Jurnal Peternakan Indonesia. 19(1): 10-15.

Dengah, S. P. 2016. Pengaruh Penggantian Tepung Ikan Dengan Tepung Manggot (Hermetia Illunces) Dalam Ransum Terhadap Performans Broiler. Skripsi Fakultas Peternakan, Universitas Sam Ratulangi. Manado

Haryadi, D. 2007. Pengaruh Pemanfaatan Bakteri Penghasil Fitase Pantoea Agglomerans) Dalam Ransum Terhadap Kualitas Karkas Ayam Broiler. Skripsi. Fakultas Pertanian. Universitas Sebelas Maret. Surakarta.

Husna, V. N. 2016. Bobot potong, bobot bagian edible dan in edible ayam hasil persilangan pejantan bangkok dengan betina ras petelur. Students EJournal 5(4): 1-10.

Iskandar, S., H. Resnawati dan T. Pasaribu, 2000. Growth and Carcass responses of Three Lines of Local Chickens and its Crossing to Detary Lysine and Methionine. In the Proc. Of the 3rd International Seminar on Tropical Animal Production: Animal Production and Total Management of Local Resources. Faculty of Animal Science - Gadjah Mada University.

Iskandar, S. 2005. Pertumbuhan AyamAyam Lokal Sampai Dengan Umur 12 Minggu Pada Pemeliharaan Intensif" Dalam Prosiding Loka karya Nasional Inovasi Teknologi Pengembangan Ayam Lokal. Pusat
Penelitian dan Pengembangan Peternakan. Bogor.

Kogoya, D., J.S. Mandey, L.J. Rumokoy, dan M.N. Regar. 2019. Penambahan daun gedi (Abelmoschus Manihot (L) Medik) sebagai "Additive" dalam air minum dan pengaruhnya terhadap performans ayam kampung super. Zootec 39(1), 82-92.

Mandey, J. S., Soetanto, O. Sjofjan, B. Tulung. 2013. The effect of native gedi leaves (Abelmoschus Manihot (L) Medik) of nothern sulawesiindonesia as a source of feedstuff on the performance of broiler. Int. J. Of Biosciences 3(10): 82-91.

Muryanto, P.S. Hardjosworo, R. Herman, dan H. Setijanto. 2002. Evaluasi karkas hasil persilangan antara ayam kampung jantan dengan ayam ras petelur betina. J. Anim. Prod. 4(2):71-76.

Nahashon, S. N., N. Adefope, A. Amenyenu And D. Wright. 2005. Effects of dietary metabolizable energy and crude protein concentration on growth performance and carcass characteristics Of French Guinea Broiler. Poult. Sci. 84: 337-344.

Setiadi, D., K. Nova, dan S. Tantalo. 2013. Perbandingan bobot hidup, karkas, giblet, dan lemak abdominal ayam jantan tipe medium dengan strain berbeda yang diberi ransum komersial broiler. Jurnal Ilmiah Peternakan Terpadu, 1(2).

Sukmawati, N. M. S., Sapurna, I. P., Wirapartha, M., Sitti, N. W., Dan Ardika, N. 2015. Penampilan 
Dan Komposisi Fisik Karkas Ayam Kampung Yang Diberi Jus Daun Pepaya Terfermentasi Dalam Ransum Komersial. Majalah Ilmiah Peternakan 18(2).

Steel, R. G. D. And J. H. Torrie. 1995. Prinsip Dan Prosedur Statistika. Terjemahan B. Sumantri. Pt. Gramedia. Jakarta.

Suparno. 1994. Ilmu dan Teknologi Daging. Gajah Mada University Press. Yogyakarta.

Tasse, A. M. (2016). Performans Ayam Kampung Super Pada Pakan Yang Disubttusi Dedak Padi Fermentasi Dengan Fermentor Berbeda. Jurnal Ilmu Dan Teknologi Peternakan Tropis 3(2):21-29. 